\title{
準天頂衛星軌道の特性評価*1 \\ Characteristic of the Orbit of Quasi Zenith Satellite
}

\author{
前田裕昭*2・川口佳 久*2 ・安田明生*3
}

Hiroaki MAEDA, Yoshihisa KaWAGUCHI and Akio YASUdA

Key Words : Space Engineering, Navigation, Quasi Zenith Satellite System, Orbit Perturbation

\begin{abstract}
Quasi Zenith Satellite System is a satellite navigation system to serve over the whole area of the East Asia and the Oceania region. The ground trace of the satellite changes gradually due to the orbit perturbation caused by the earth gravity, moon, sun and solar radiation pressure. To study maintenance of the ground trace it was needed to know the characteristics of the orbit. In this paper we described the characteristics of the longitude of ascending node $L A N$, the eccentricity $e$ and the other parameters. The earth Non-Zonal term induces the harmful perturbation onto the semi major axis $a$, which directly relates the longitude of ascending node $L A N$ and the average longitude of the ground trace. The fluctuation of the eccentricity $e$ is depend on right ascension of ascending node $\Omega$, and is not negligible. The orbit which has the right ascension of ascending node $\Omega=210 \mathrm{deg}$ is the most stable orbit. And we also suggest that it is important to control two parameters, the eccentricity $e$ and the semi major axis $a$ to maintain the ground trace. The maintenance interval should be from 6 months to 12 months.
\end{abstract}

\section{1. ま え がき}

準天頂衛星測位システム（以下 QZSS と呼ぶ）では，地 上軌跡が東経 135 度を中心とし 8 の字を描く軌道（以下 QZO と呼ぶ）に衛星（以下準天頂衛星, あるいは, QZS と呼ぶ）を軌道上に打ち上げて, 日本を中心とした東アジ アやオセアニアに測位サービスを提供する.しかし, 軌道 は, 地球質点重力以外に, Zonal 項や Non Zonal 項等の非 球対称地球重力項の影響や, 太陽や月の重力, 太陽輻射圧 の影響を受ける. そのため, それぞれの影響の大きさがど の程度であって, どれだけの期間でそれらを補正する必要 があるか，またその補正に必要な速度増分量がどれくらい かの把握は, QZSS 及び QZS の研究開発において主要な 課題の一つであった.

この研究課題については, 既に幾つかの検討がなされて いる 1）2）が，いずれも断片的であったり，視点が異なる.

今回我々は, 主に, 軌道傾斜角 $i=45 \mathrm{deg}$, 離 心率 $e=0.099$, 近地点引数 $\omega=270 \mathrm{deg}$, 及 び, 地上軌跡の中心を東経 $135 \mathrm{deg}$ (これは昇交点経度 $L A N($ Longitudeof AscendingNode $)=146.5 \mathrm{deg}$ に相当 する）とする軌道が受ける摂動を解析し, その特性を評価 した.

2. では, Zonal 項について, 2 体問題と対比させて述心 る. Zonal 項は, 主として昇交点赤経 $\Omega$, 近地点引数 $\omega$, 平 均近点離角 $l$, 及び昇交点赤経 $\Omega$ と平均近点離角 $l$ の変動に

\footnotetext{
*1 $\bigcirc 2007$ 日本航空宇宙学会

平成 19 年 1 月 29 日原稿受理

*2 NEC 東芝スペースシステム（株）

$* 3$ 東京海洋大学
}

起因して昇交点経度 $L A N$ に影響を与える。これら Zonal 項による昇交点赤経 $\Omega$, 近地点引数 $\omega$, 平均近点離角 $l$ の変 動は，永年摂動項としてよく知られている。ここでは，永 年摂動項に関しては, 軌道長半径 $a$ の調整により, 昇交点 経度 $L A N$ がほぼ変動しないようにすることができること を示す.

3. では, 地上軌跡変動に主要な影響を与える Non Zonal 項についてその影響が経度に依存することを示す. Non Zonal 項は地球の経度に関係するものであって, 主として 軌道長半径 $a$ に影響を与え, その影響の様子は静止衛星に 対するものと似ている。適切な頻度での東西制御が必要で ある。

4.では太陽輻射圧の影響, 太陽と月の重力の影響を, 昇 交点赤経 $\Omega$ ごとに評価した５．では研究・考察の検討を まとめて，むすびとした．

なお，高度が高いので大気抵抗は考える必要は無い。ま た, 発熱量はせいぜい $5 \mathrm{~kW}$ であって, 太陽輻射圧の 10 分 の 1 程度であり，しかも衛星の $\pm \mathrm{Y}$ 面から均等に熱排出さ れていて今回の軌道摂動の検討のレベルでは影響を与えな いことから，熱輻射圧力はここでは取り扱わない.さらに, $\mathrm{RF}$ 放射量は $300 \mathrm{~W}$ であって，太陽輻射圧の 100 分の 1 程 度であり，かなり小さいのでこれも考慮しない.

\section{Zonal項の影響}

地球の一日 $1440 \mathrm{~min}$ は太陽との関係で決められている. 一方, 地球は太陽の回りを約 365.24219days かけて公転し ている. そのため, 地球は一日の間に, 慣性空間において $1 \frac{1}{365.24219 d a y}$ 回転することになる. したがって, 慣性空間に 
おける地球の 1 回転の軌道周期 $T$ は， $1436.07 \mathrm{~min}=86164 \mathrm{~s}$ である. 基準とする $\mathrm{QZO}$ の軌道周期 $T$ をこの值に設定 する. なお，本論文で前提とするその他の軌道要素は，そ れぞれ， $i=45 \mathrm{deg}, e=0.099$ (最大),$\omega=270 \mathrm{deg}$, $L A N=146.5 \mathrm{deg}$ とする.

さて，ここでまず, Zonal 項について評価する. Zonal 項 は，軌道と地球の緯度との関係による項であり，ここで述 べる評価結果は $\Omega$ や $L A N$ に関わらず有効である.

まず， $\Omega$ は，永年摂動項として知られた以下の式 $(1)$ により, - $\cos i$ に比例して変動する 3)4)5). ここで， $J_{2}$ は ZONAL 地球重力項の $J_{2}$ 項のことであり, $R_{e}$ は地球の半 径, $a, e, i$ はそれぞれ軌道長半径, 離心率, 軌道傾斜角で ある。

$$
\triangle \Omega \approx-\frac{3}{2} J_{2} \frac{R_{e}^{2} \times n}{a^{2} \times\left(1-e^{2}\right)^{2}} \times \cos i
$$

STK による解析によれば，第 1 図に示すように， $\Omega$ が $-3.53 \mathrm{deg} /$ year で直線的に小さくなり, 上式と一致する. 図にあるように， $i$ の大きさに依存するが， $e$ が 0.099 から 0.08 程度である時, $e$ への依存度は大きくない。

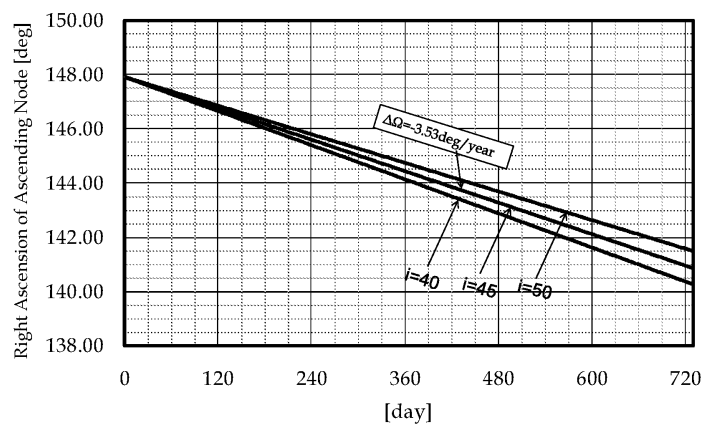

第1図 Zonal 項に起因する昇交点赤経 $\Omega$ の変動

同様に， $\omega$ は，永年摂動項として知られた下式 $(2)$ に より, $i=63.4 \mathrm{deg}$ の時を境にして，符号が変わる.

$$
\triangle \omega \approx \frac{3}{2} J_{2} \frac{R_{e}^{2} \times n}{a^{2} \times\left(1-e^{2}\right)^{2}} \times\left(2-\frac{5}{2} \sin ^{2} i\right)
$$

解析によれば，第 2 図に示すように， $\omega$ が $+3.75 \mathrm{deg} /$ year で直線的に変化している，i には依存するが， $e$ に依存する 変動は無視できる。

同様に, 平均近点離角 $l$ は, 永年摂動項として知られた 下式 ( 3 ) により， $i=54.7 \mathrm{deg}$ の時を境にして，符号が 変わる. $i=45 \mathrm{deg}$ で $e=0.099$ の時, 平均近点離角 $l$ は $1.24 \mathrm{deg} /$ year で大きくなる.

$$
\triangle l \approx \frac{3}{2} J_{2} \frac{R_{e}^{2} \times n}{a^{2} \times\left(1-e^{2}\right)^{3 / 2}} \times\left(1-\frac{3}{2} \sin ^{2} i\right)
$$

さて, $\Omega$ が変動すると $L A N$ も同様に変動する.すなわ ち，仮に $\triangle \Omega$ が負であるときは，LAN が西に移動すると いうことになる。しかしその場合は， $T$ を短くすれば $L A N$

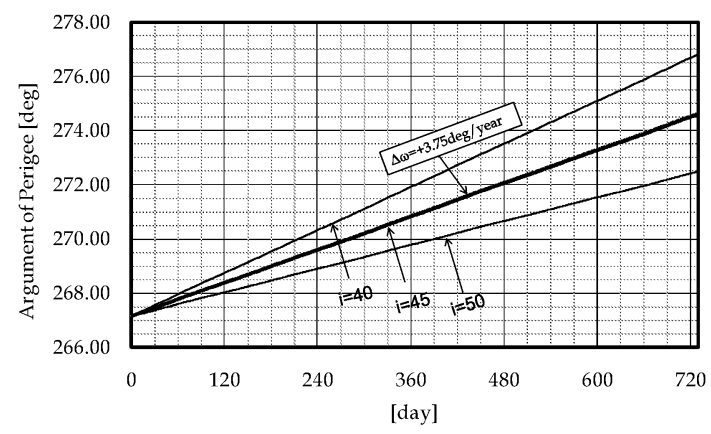

第 2 図 Zonal 項に起因する近地点引数 $\omega$ の変動

の西への移動は抑えられるわけで， $L A N$ の変動をゼロに するためには， $T$ を $\triangle T_{\Omega}=\frac{\triangle \Omega}{\dot{\Omega}_{e}}$ だけ短くすれば良い。こ こで， $\Omega_{e}$ は地球の自転速度である.

一方， $\omega$ と平均近点離角 $l$ の変動は， $T$ を変動させるの と同じ効果を持つ.たとえば，QZOのケースだとこれらの 変動は共に正であるので, $T$ が短くなった効果と同じであ る. そして, その効果は, $\triangle T_{\omega+l}=\frac{\Delta \omega+\Delta l}{n_{0}}$ である.ここ で, $n_{0}$ は平均運動である.

これら 2 つを合わせて, 式 $(4)$ に示すように $T$ を変え るという対策を施すことで， $L A N$ の経年変動を抑えるこ とができる．つまり，この QZO の場合だと，二体問題の 場合の $T$ が $1436.07 \mathrm{~min}$ であったのに対し，1436.084min とするのである. これら, 対策前後の $L A N$ の経年変動に ついては第 3 図に示す通りである.

$$
\triangle T \approx \triangle T_{\omega+l}-\triangle T_{\Omega}=\frac{\triangle \omega+\triangle l}{n_{0}}-\frac{\triangle \Omega}{\dot{\Omega}_{e}}
$$

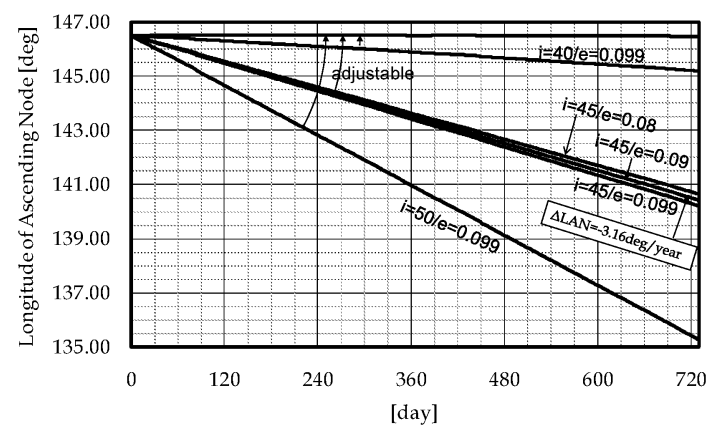

第 3 図 Zonal 項に起因寸る昇交点経度 $L A N$ の変動と軌道周期 $T$ の 調整による LAN の維持

その他の軌道パラメータである $e, i$ の Zonal 項による経年 変化は小さく，それぞれ $\pm 0.00002 /$ year，+0.003deg/year 程度で無視できる。

\section{Non Zonal 項の影響}

Zonal 項に Non Zonal 項を加えて，解析評価した．NonZonal 項は，軌道と地球の経度との関係であり， $\Omega$ に関わ らずここで述べる評価結果は有効である.

まず，地球同期軌道である準天頂軌道は，静止衛星と同 
様な影響を NonZonal 項から受けることを改めて確認した。 すなわち，その軌道を放置すれば，静止衛星と同様に第 4 図 に見られるように $a$ が変化し, それにより軌道周期 $T$ が変動 してその地上軌跡はインド洋上空にずれていく. $a$ の一日あ たりの変化率は, 第 6 図に示すように, $L A N=110 \mathrm{deg} \sim$ 140deg で，ほぼ $+0.1 \mathrm{~km} /$ day であり，軌道周期 $T$ が長く なって，LAN が西に移動することを裏付けている. 第 5 図 にあるように $L A N$ は東経約 85 度（地上軌跡の中心は東 経約 75 度）を中心にして長期的に振動する。 また，その状 況は $\Omega$ を変えてもほとんど変わらない.

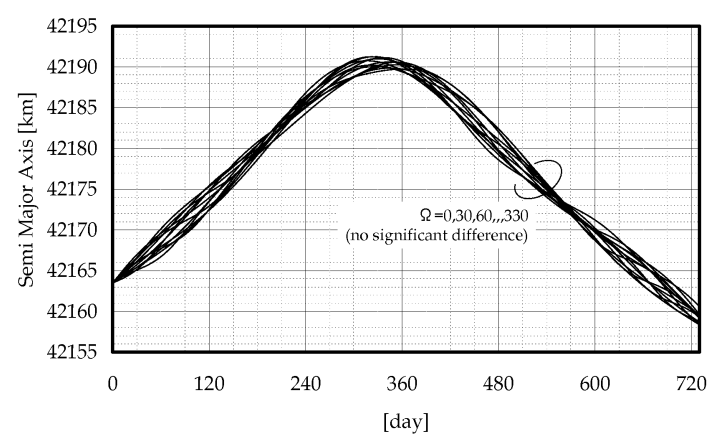

第 4 図 Non Zonal 項に起因する軌道長半径 $a$ の変動

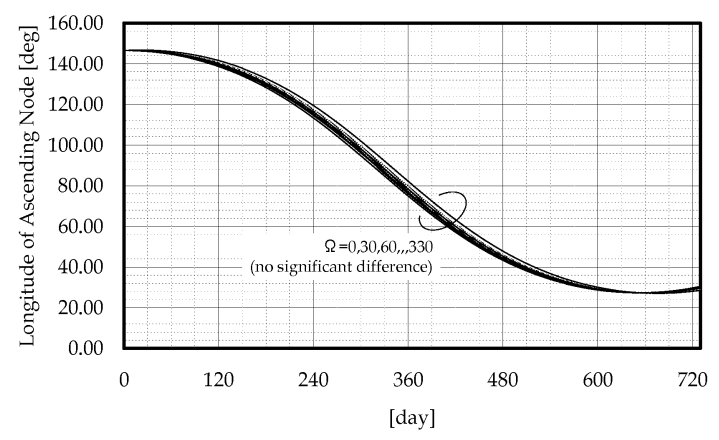

第 5 図 Non Zonal 項に起因する昇交点経度 $L A N$ の変動

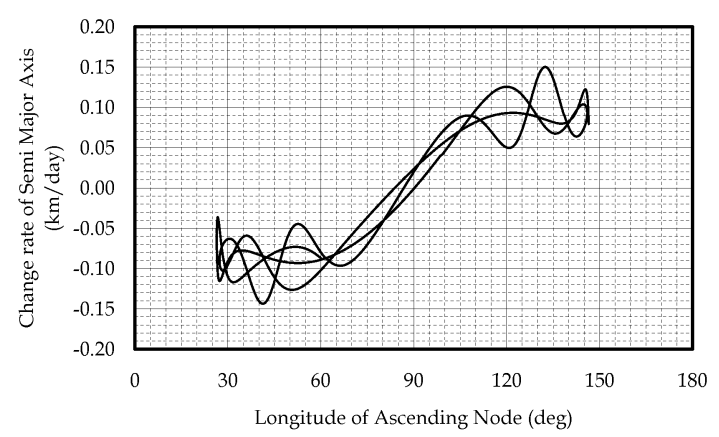

第6図 Non Zonal 項に起因寸る昇交点経度 $L A N$ と軌道長半径 $a$ との関係

これに対して， $\omega$ の変化はZonal 項の影響が支配的であ り, NonZonal 項の影響はほとんど見られないことが確認さ
れた. 更に, $e, i$ の変化は小さく, それぞれ $\pm 0.00005 /$ year, $\pm 0.05 \mathrm{deg} /$ year 程度で無視できるほどである.

$e$ が 0.09 あるいは 0.08 のケース，また $i$ が $50 \mathrm{deg}$ ある いは40degのケースにおいての解析においても, 前節で述 ベた以上の有意な差は見られない.

さて, QZS の軌道保持運用で最も重要なのは地表面軌跡 の維持であり, そのためには $L A N$ を維持しなくてはなら ない.ここで軌道保持運用間隔 $P$ を 0.5 年, 1 年, 1.5 年 と想定した。 $P$ に渡って,$L A N$ が平均的に東経 $146.5 \mathrm{deg}$ を中心に変動するように, 初期の $a$ と $L A N$ を設定した. $P$ を半年, 1 年, 1.5 年とした時の, $L A N$ の変動の様子 をプロットしたものが第 7 図であり, これらを数值として 第 1 表にまとめた。図からわかるように，当初は地上軌跡 が東に移動するうように $a$ を設定し, その後ある経度で平 衡した後に, 地上軌跡は西に移動する。Pが広がれば地上 軌跡の変動幅も広がる. 解析的には, 地上軌跡の変動幅が $P$ の 2 乗に比例することが分かっており ${ }^{2)}$, 本研究におけ る数值計算の結果もそれをほぼ裏付けている.

$P$ の長さは, QZS の寿命 10 年で必要とする合計推薬量 にはあまり影響を与えない。しかし，Pが短いと，その間 の測位サービス停止により，QZSS としての稼働率に悪い 影響を与える. 一方で, $P$ が長いと, $L A N$ の変動が大きく なるので, 地上のサービスエリア, 特に日本から QZS を見 込む仰角が低くなるなど，可視性に悪い影響を与える。 そ のため, 別の解析によれば, $L A N$ の変動の目安としては $\pm 5 \mathrm{deg}$ であるとこがわかっており, その場合 $P$ は 0.7 年程 度になる。

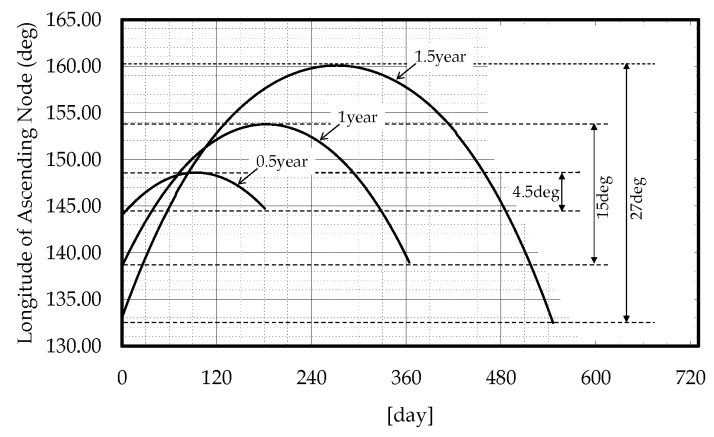

第 7 図 軌道長半径 $a$ をそれぞれ 0.5 年, 1 年, 1.5 年で調整した時 の昇交点経度 $L A N$ の変動

第 1 表 軌道保持運用間隔 $P$ と昇交点経度 $L A N$ の変動, 及び, 軌 道長半径 $a$ との関係

\begin{tabular}{|c|c|c|c|}
\hline 軌道保持運用間隔 $P$ & 0.5 年 & 1 年 & 1.5 年 \\
\hline$a$ の初期値 & $42156 \mathrm{~km}$ & $42150 \mathrm{~km}$ & $42145 \mathrm{~km}$ \\
\hline$P$ の間の $a$ の変動 & $15 \mathrm{~km}$ & $28 \mathrm{~km}$ & $37 \mathrm{~km}$ \\
\hline$L A N$ の変動幅 & $4.5 \mathrm{deg}$ & $15 \mathrm{deg}$ & $27 \mathrm{deg}$ \\
\hline
\end{tabular}




\section{4. 月, 太陽の影響}

2 体問題に加えて, 月重量, 太陽重力, 太陽輻射圧の影 響を考慮した。一方，ここでは，簡単のために非球対称成 分 (Zonal 項及びNon Zonal 項) を除外して解析を進めた. なぜなら, 既に非球対称地球重力成分による $L A N$ の影響 度合いが分かっており, それを $a$ の調整により維持するこ ととしていること，及び， $\omega, e, i$ の非球対称成分による 影響も同様に把握されているからである.

各 $\Omega$ での, $L A N, e, i$, 及び $\omega$ の 2 年間の変動を, そ れぞれ第 8 図, 第 9 図, 第 10 図, 第 11 図に示す.いず

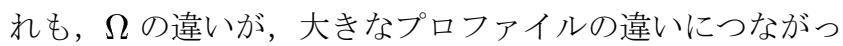
ている.しかし，そのプロファイルは，ほぼ単調な動きで あり，例えば QZS の設計寿命である 10 年に対しては，単 純に外挿して考えることも可能である。また，例えば昇交 点赤経 $\Omega=58 \mathrm{deg}$ に QZS を投入すると, $i$ については $0.65 \mathrm{deg} /$ year で変動するので，初期に投入する軌道の $i$ を $41.75 \mathrm{deg}$ にしておげ， 10 年後には 48.25deg になること が容易に分かるなど，軌道保持運用戦略の指針となる.

なお， $e$ が 0.09 あるいは 0.08 となるにしたがって $e$ の 変化率は $20 \%$ ほ ぼささなる。 また， $i$ が50deg あるいは 40deg と変えたケースでは, $40 \mathrm{deg}$ の方が比較的その変化 率は小さいものの，有意な差は見られない.

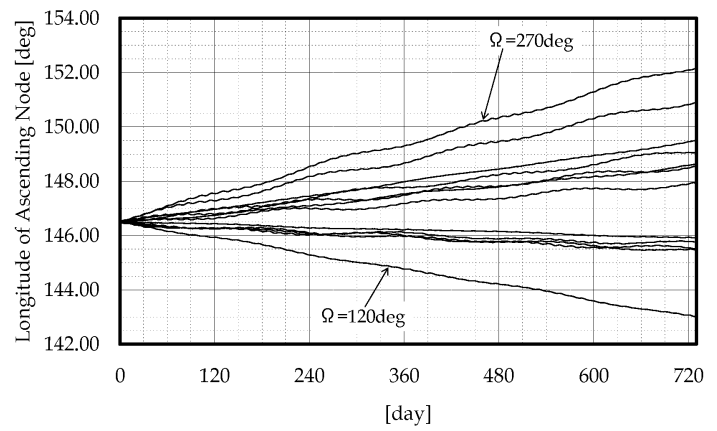

第 8 図 各昇交点赤経 $\Omega$ での月及び太陽による昇交点経度 $L A N$ の 変動

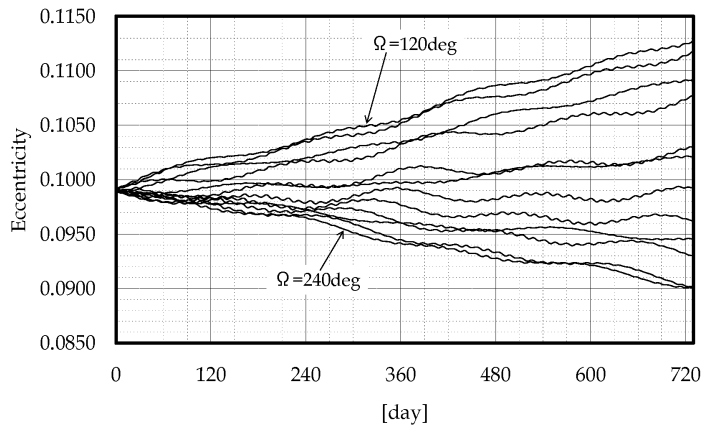

第 9 図 各昇交点赤経 $\Omega$ での月及び太陽による離心率 $e$ の変動

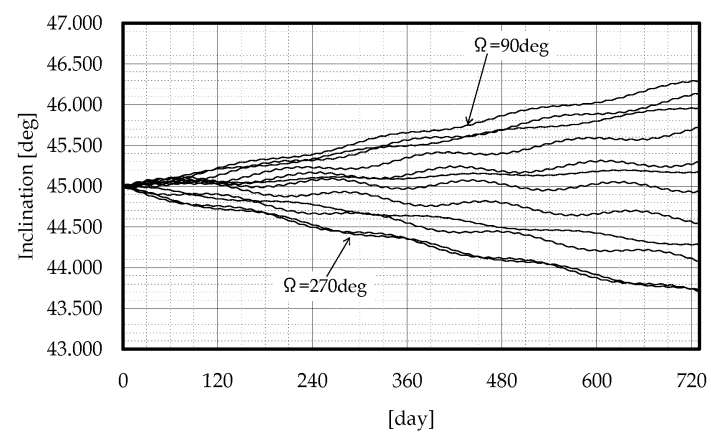

第 10 図 各昇交点赤経 $\Omega$ での月及び太陽による軌道傾斜角 $i$ の変動

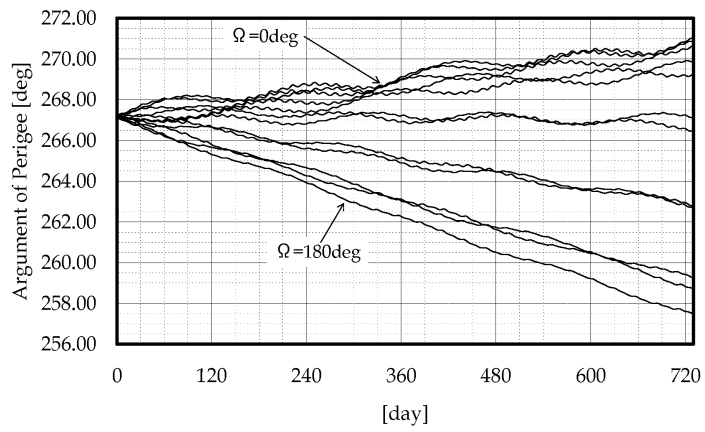

第 11 図 各昇交点赤経 $\Omega$ での月及び太陽による近地点引数 $\omega$ 昇交点 経度 $L A N$ の変動

\section{5. 各摂動源の影響のまとめと評価}

第 12 図に示したのは，ある $\Omega$ を横軸にとった時の， $i$,

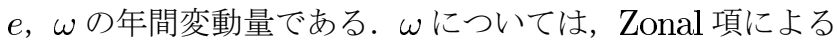
永年摂動量 $3.75 \mathrm{deg} /$ year を加えている. この図により，1 年間の変動の大きさを把握することができ，軌道保持運用 の検討に資することになる.

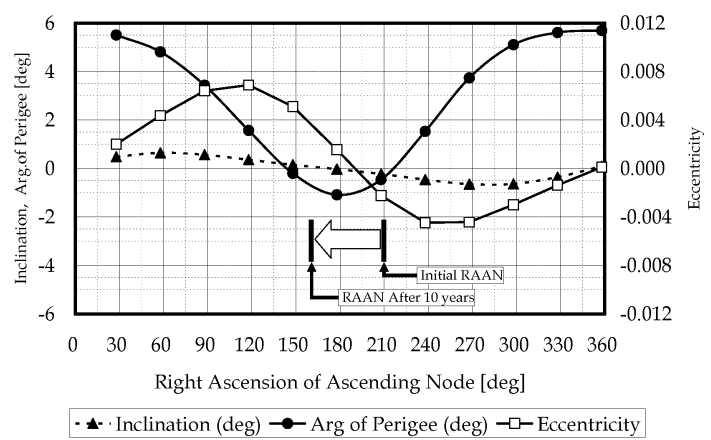

第 12 図 各 RAAN ごとの軌道パラメータの 1 年間での変動

そこで，第 13 図に示したのは，投入される $\Omega$ を横軸と して，10 年間の $\Omega$ の経年変動を全て考慮した時の， 10 年 間の軌道パラメタータの変動量を示す．経年変動を全て考 慮するとは， $\Omega$ が Zonal 項により - 3.53deg/year で変動 し，それに加えて月や太陽の影響により -1.2deg/year〜 -1.5deg/year 変動することを考慮するということであり, それらが 10 年かけてほぼ - 50deg 変動することを考慮す ることを意味する。この図により，QZS の寿命である 10 
年間での，それぞれのパラメータの合計変動量を把握する ことができる。

$i$ の変動幅は最大で－5.8deg～5.5deg である. 仮に, これ を保持制御するのであれば，昇交点赤経 $\Omega=20 \mathrm{deg}, 200 \mathrm{deg}$ の時が制御量が最も小さくなる. $\omega$ の変動幅は, $-6 \mathrm{deg} \sim$ +58deg であるが，昇交点赤経 $\Omega=135 \mathrm{deg} \sim 270 \mathrm{deg}$ であ ればその変動幅は $20 \mathrm{deg}$ に満たない. 仮にこれを保持制御 するのであれば，昇交点赤経 $\Omega=175 \mathrm{deg} \sim 240 \mathrm{deg}$ の時 が制御量が最も小さくなる. $e$ の変動幅は $-0.04 〜+0.06$ に達していて大きく, その保持制御は必須である. $e$ の保 持制御量が最も小さくなるのは, 昇交点赤経 $\Omega=20 \mathrm{deg}$, 210degの時である.

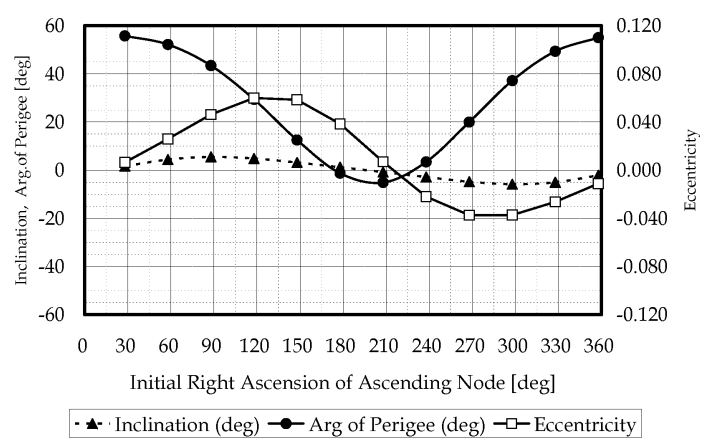

第13図＼cjkstart各 RAAN ごとの軌道パラメータの 10 年間での変動

\section{6. む す び}

本論文では, QZS の軌道摂動についての研究成果をまと めた. まず，永年摂動項による昇交点経度 $L A N$ の変動は, 軌道長半径 $a$ の調整により, 変動しないようにすることが できる. 地上軌跡の東西方向の変動は, その軌道保持運用 間隔 $P$ を半年とすると, その時の軌道長半径 $a$ の毎回の制 御量は $15 \mathrm{~km}$ であり, 昇交点経度 $L A N$ の変動は $4.5 \mathrm{deg}$ 以 内である. 10 年間の軌道傾斜角 $i$ の変動幅は最大で $7 \mathrm{deg}$ 程度であり, QZSSのサービス仕様次第では, その変動幅 が許容して放置することもできることを示唆した．同様に， これも QZSS サービス仕様によるが，仮に初期の昇交点赤

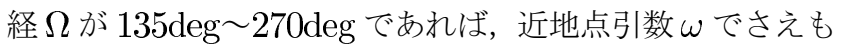
その変動幅は 20deg 以下であるので放置が可能である. な お, 離心率 $e$ の変動は大きいため, 軌道保持運用間隔 $P$ に 実施する軌道長半径 $a$ の毎回の制御と併せて, 保持制御さ
れることが望ましいことも分かった。

\section{7. 解析条件のまとめ}

解析には, STK（v4.3.0）を使用した。積分は 7 次の Runge Kutta Fehlberg 方式で行い，積分のステップ時間 は 0.5min,2min,5min,10min,20min の全ての場合の積分結 果が等しく変わらないことを確認したうえで，10min とし た.また, 地球重力の次数は，5, 10, 20, 40 次で同一であ ることを確認した上で, 20 次とした. 更に, 太陽輻射圧に 関連するパラメータとしては, $C_{S R P}=1.2$, 衛星の質量は $m=2000 \mathrm{~kg}$, 衛星の太陽方向の投影断面積は $A=31 \mathrm{~m}^{2}$ とし，いずれも太陽輻射圧が大きく評価されるようにした. また，太陽輻射圧に関連する衛星の姿勢は，衛星の Z 軸が 常に地球を向くようにし, 衛星の XZ 平面内に太陽方向べ クトルが入るようにした.

解析の開始時刻は 2010 年の 1 月からとして, その最初 の 2 年間分を 2020 年まで外挿して評価した. 月軌道と黄 道の交点の変動周期は約 18.6 年であり, その軌道に与える 影響が最大化するのが 2006 年, 最小化するのが 2015 年で ある. 影響度合いの最大最小の比は，1.2 程度である. QZS の 1 号機が実際に運用されるのは 2010 年から 2020 年にか けてであるので，実際には最も月と太陽の影響を受けにく い期間であると言え, 2010 年からの 2 年間を 10 年分外挿 することは，影響を大きめに評価することになり，開発の 指針となる.

解析は, 新衛星ビジネス株式会社の STK (Satellite Took Kit) 及び計算機を使用させていただいた. この場を借りて, 謝意を表す.また，準天頂衛星プロジェクトの立ち上げに おける同社及び関連する諸兄の多大なる貢献に対して, 大 いなる敬意を表する.

\section{参 考 文 献}

1）川口佳久, 木村和宏 : 準天頂衛星の軌道選定, 2004 年総合大会, 電 子情報通信学会, 2004 .

2) 木村和宏 : 軌道保持制御を簡略化した場合の準天頂衛星軌道の長期 変化, 第 50 回宇宙科学技術連合講演会, 日本航空宇宙学会, 2006 .

3) Thomson W.T: Introduction to Space Dynamics, John Wiley and Sons, Inc., New York, 1961.

4) Bate R.R, Mueller D.D, White J.E: Fundamentals of Astrodynamics, Dover Publications, Inc., New York, 1971.

5) Montenbruck O, Gill E: Satellite Orbits, Springer, Germany, 2001. 